\title{
Operation of TUT Solar PV Power Station Research Plant under Partial Shading Caused by Snow and Buildings
}

\author{
Diego Torres Lobera, ${ }^{1}$ Anssi Mäki, ${ }^{1}$ Juha Huusari, ${ }^{2}$ Kari Lappalainen, \\ Teuvo Suntio, ${ }^{1}$ and Seppo Valkealahti ${ }^{1}$ \\ ${ }^{1}$ Department of Electrical Engineering, Tampere University of Technology, P.O. Box 692, 33101 Tampere, Finland \\ ${ }^{2}$ ABB Corporate Research, Segelhofstrasse 1K, Baden-Dättwil, 5405 Aargau, Switzerland \\ Correspondence should be addressed to Diego Torres Lobera; diego.torres@tut.fi
}

Received 22 January 2013; Accepted 11 June 2013

Academic Editor: Keith Emery

Copyright (C) 2013 Diego Torres Lobera et al. This is an open access article distributed under the Creative Commons Attribution License, which permits unrestricted use, distribution, and reproduction in any medium, provided the original work is properly cited.

\begin{abstract}
A grid connected solar photovoltaic (PV) research facility equipped with comprehensive climatic and electric measuring systems has been designed and built in the Department of Electrical Engineering of the Tampere University of Technology (TUT). The climatic measuring system is composed of an accurate weather station, solar radiation measurements, and a mesh of irradiance and PV module temperature measurements located throughout the solar PV facility. Furthermore, electrical measurements can be taken from single PV modules and strings of modules synchronized with the climatic data. All measured parameters are sampled continuously at $10 \mathrm{~Hz}$ with a data-acquisition system based on swappable I/O card technology and stored in a database for later analysis. The used sampling frequency was defined by thorough analyses of the PV system time dependence. Climatic and electrical measurements of the first operation year of the research facility are analyzed in this paper. Moreover, operation of PV systems under partial shading conditions caused by snow and building structures is studied by means of the measured current and power characteristics of PV modules and strings.
\end{abstract}

\section{Introduction}

The cost of photovoltaic (PV) power systems is decreasing with evolving technology, and PV power plants are approaching grid parity in several market areas [1] and heading for an era of market competition without subsidies. Main research and development efforts have been at the component level, such as improving the efficiency of PV cells and grid interfacing devices. Therefore, major progress in the energy efficiency of basic components is not expected in the near future, and more competition will be set to decrease production costs of components. Due to this and the competition without subsidies, system vendors face increasing pressure to provide more value for customers. One way of doing that is to improve the overall system efficiency and the amount of actual power produced under installation site conditions. Improvements in the design and operation of PV power plants are one evident and feasible way to substantially increase the produced power [2].
Accurate modeling of the electric behavior of PV modules and systems will be a key element in improving system operation and efficiency [3]. For instance, accurate modeling of the operation of PV generators under varying environmental conditions improves their performance control and assists the design of $\mathrm{PV}$ converters and their maximum power point tracking (MPPT). PV power plants are composed of PV modules connected in series and parallel to reach adequate voltage and power levels. Furthermore, PV modules are composed of PV cells connected in series. It has been shown that environmental effects causing nonuniform operating conditions can lead to power losses of the order of $10 \%$ in typical PV power plants [2]. These nonuniform operating conditions can be due to various reasons, such as partial shading of the PV generator by built structures, and clouds. For example, climatic effects influence the electrical characteristics of PV cells directly via incident irradiance and indirectly via module temperature, which depends on ambient temperature, incident irradiance, relative humidity, 
TABLE 1: Electrical performance of the NP190GKg PV module under STC.

\begin{tabular}{lcccc}
\hline$P_{\mathrm{MPP}}(\mathrm{W})$ & $U_{\mathrm{MPP}}(\mathrm{V})$ & $I_{\mathrm{MPP}}(\mathrm{A})$ & $U_{\mathrm{OC}}(\mathrm{V})$ & $I_{\mathrm{SC}}(\mathrm{A})$ \\
\hline 190.00 & 25.80 & 7.36 & 33.00 & 8.00 \\
\hline
\end{tabular}

and wind speed and direction, among others [4]. These variables must be taken into account when modeling the dynamic operation of photovoltaic systems [5-8].

Under partial shading conditions, PV cells connected in series experience different irradiance levels. The resulting electrical characteristics deviate from their standard form, depending on the shading pattern and intensity. Extensive research exists on the effects of partial shading on the operation of PV modules and systems [9-14]. For PV modules with more than one bypass diode, the $P-U$ characteristic curves turn into multipeak curves which impede maximum power point tracking operation [15]. Significant energy losses can take place, and the overall system performance reduces [16].

The TUT solar PV power station research plant has been designed to enable systematic and thorough analysis of the dynamic phenomena in energy conversion processes in solar PV power systems. In this paper, we justify the built PV solar power research plant and measuring system, such as the selected sampling frequency of climatic and environmental data. We also demonstrate the applicability of the research facility by analyzing the climatic and electrical measurements of the first operational year. Additionally, operation of PV systems operating under partial shading conditions caused by snow and building structures is analyzed in this paper.

\section{TUT Solar PV Power Station Research Plant}

2.1. PV Generator. The research plant consists of 69 NP190GKg PV modules with a total peak power of $13.1 \mathrm{kWp}$. Each PV module consists of 54 polycrystalline silicon solar cells connected in series, physically located as 6 horizontal rows and encapsulated in EVA with a $4 \mathrm{~mm}$ iron tempered glass as top cover. Table 1 includes the PV module's electrical performance under standard test conditions (STC).

The PV modules, designed for grid connected PV applications, include 3 protection bypass diodes connected in parallel to the cells. Each diode protects a group of $18 \mathrm{PV}$ cells (2 horizontal rows) preventing them from hot spotting by driving the current if any of the cells is shaded. However, PV modules protected with bypass diodes can generate several maximum power points (MPPs), when operating under partial shading conditions [17].

In the basic configuration, the TUT PV system is composed of 3 series-connected strings of $17 \mathrm{PV}$ modules and 3 strings of 6 modules with MPP voltages of $440 \mathrm{~V}$ and $155 \mathrm{~V}$ at STC, respectively. Actually, all possible electrical configurations with the 69 modules can be set and utilized. The location of PV strings has been carefully selected to avoid complete shading of strings during any time of the day or year. However, several groups of modules are partially shaded during different seasons of the year at different times of the day as seen in Figure 1. This characteristic permits us to

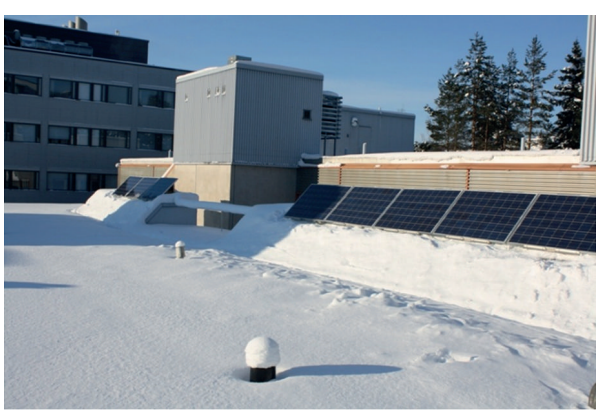

FIGURE 1: Example of partial shading of a PV string due to a building structure on a sunny day during spring 2012.

undertake research on different environmental aspects such as MPPT in cases of partial shading due to building structures [17].

The layout of the TUT solar power station research plant is illustrated in Figure 2. It shows the PV strings and modules located through most of the rooftop of the Department as well as the location of the different sensors of the measuring systems, which will be further described in the next chapter.

2.2. Climate Measuring System and Data Acquisition. The climatic measuring system is composed of an inclusive state of the art weather station and a mesh of irradiance and PV module temperature measurements. The sensor mesh is positioned throughout the PV power facility and records the operating conditions of every PV module string of the plant. The novelty of the climatic measuring systems comes from the data-acquisition system, which collects measurements continuously from all sensors with a $10 \mathrm{~Hz}$ sampling frequency. This means that even the fastest dynamical phenomena affecting the operation of the PV power plant are noticed.

The automatic weather station [18] measures the global atmospheric conditions under which the PV facility is operating. It includes measurements of ambient temperature and relative humidity, and wind speed and wind direction, as well as incoming global and diffuse solar radiations on the horizontal plane. The weather station measures global solar radiation with the pyranometer CMP22 (Kipp\&Zonen) and diffuse component of the radiation with the pyranometer CMP21 (Kipp\&Zonen) combined with a shadow ring CMC121 (Kipp\&Zonen), blocking the direct solar radiation. Wind speed and direction are measured with an ultrasonic wind sensor WS425 (Vaisala), and ambient temperature and humidity are measured with with the sensor HMP155 (Vaisala).

The weather station comprises equipment in two different locations of the roof. The CMP21 pyranometer mounted with the shadow ring, the HMP $155_{\mathrm{T}}$ ambient temperature sensor, and the $\mathrm{HMP} 155_{\mathrm{H}}$ relative humidity sensor are located on the lower rooftop for accessibility and safer adjustment of the shadow ring, especially during winter when the roof is covered with snow and ice. The CMP22 pyranometer and the WS425 wind sensor are located at the highest point of the 
rooftop to measure the overall solar radiation and the wind profile at the power plant with minimum disturbance due to the building structures.

The mesh of irradiance and module temperature sensors is composed of 21 pairs of SPLite2 photodiodes (Kipp\&Zonen) and Pt100 temperature sensors. These pairs are located at the ends of every PV module string, thus providing detailed information on the operating condition at string and module levels. The photodiodes are mounted with the same tilt angle as the PV modules, and the Pt100 sensors are attached to the back plates of the solar modules. Location of these sensors in the PV plant is shown in Figure 2, and installation is shown in Figure 3.

All the climatic data are acquired, transmitted, and recorded continuously in a database making them accessible for later analysis. The data-acquisition system is based on CompactRio data-acquisition cards from National Instruments enabling a flexible and economical system that uses specific swappable I/O modules to connect the sensor outputs. After collecting the data from the sensors, these cards transmit the data to a PC through Ethernet cable without interference or noise problems.

The database is based on PostgreSQL system, an opensource database management system available for several platforms including Linux, Mac OS X, or Microsoft Windows. This system enables information modification and extraction without blocking the storage process. The data is accessed using SQL queries from any computer connected to local area network of the department.

The sampling frequency of climatic measurements is a key parameter since the database will continuously store data acquired from 48 sensors. It has to be fast enough to detect even the fastest phenomena affecting the electrical operation of the PV system, but simultaneously be as long as possible because of the vast amount of data to be processed, as well as the storage needs. Among the climatic variables to be acquired, the solar radiation has the highest and fastest variations; for example, there can be changes of over $700 \mathrm{~W} / \mathrm{m}^{2}$ within seconds in days with moving clouds. Therefore, it was essential to find out the sampling frequency required to detect even the fastest phenomena related to power generation with PV power plants. The simplest way to achieve this was to use a $\mathrm{PV}$ module as a solar radiation sensor and evaluate the effect of sampling frequency from the measurements.

Figure 4 illustrates the measured short-circuit current $I_{\mathrm{SC}}$ of a single PV-module during 7 hours on July 1st, 2010, with a sampling frequency of $25 \mathrm{~Hz}$. When the PV module is shortcircuited it acts as a solar radiation sensor with its output current linearly changing with the incoming irradiance. A sampling frequency of $25 \mathrm{~Hz}$ was considered to be high enough to detect even the fastest changes in irradiance causing an effect on the PV module. A partially cloudy day with moving clouds was chosen to provide the climatic conditions needed to evaluate such effects.

Figure 4 shows values of $I_{\mathrm{SC}}$ from 1.05 to $10.06 \mathrm{~A}$, which correspond to irradiance levels between 131 and $1255 \mathrm{~W} / \mathrm{m}^{2}$, respectively. Changes of $I_{\mathrm{SC}}$ up to $0.56 \mathrm{~A}\left(71 \mathrm{~W} / \mathrm{m}^{2}\right)$ happened between 2 consecutive measurements, which are roughly $5 \%$ of the maximum current during the measurement period. A change of $5 \%$ might not yet have a drastic effect on the electrical characteristic of the PV module, but with this rate of change the current goes easily from minimum to maximum value in a second or vice versa. Such fast climatic changes demonstrate the need of sampling frequency higher than $1 \mathrm{~Hz}$.

Taking the $25 \mathrm{~Hz}$ measurements as reference and downsampling the acquisition frequency permit us to evaluate the effect of sampling frequency on the accuracy of the solar radiation measurements. Figure 5 presents the standard deviation error of the measured solar radiation as a function of the sampling frequency.

Figure 5 shows inverse exponential behavior of the standard deviation error with increasing sampling rate at low sampling rates as expected. The standard deviation error starts to grow considerably, when sampling frequency goes below $5 \mathrm{~Hz}$, and increases up to $48.7 \mathrm{~W} / \mathrm{m}^{2}$ at $0.125 \mathrm{~Hz}$. Sampling frequencies over $5 \mathrm{~Hz}$ result in small standard deviation of incoming radiation below $1 \mathrm{~W} / \mathrm{m}^{2}$. Therefore, sampling frequency of $10 \mathrm{~Hz}$ was considered to be sufficient for detecting even the fastest phenomena related to power generation with PV power plants.

\section{I-U Curve Tracer to Measure Electrical Characteristics}

The experimental setup for measuring the $I-U$ characteristics of the PV generator is composed of four parallel-connected high-power IGBT modules $(1200 \mathrm{~V} / 200 \mathrm{~A})$, the gate drive circuitry, and a high-speed oscilloscope to record the current and voltage data. The setup was designed to enable an $I-U$ sweep from a string of $17 \mathrm{PV}$ modules with a peak power of $3.2 \mathrm{~kW}$. The measuring setup operates as follows: the IGBT modules act as regulating resistors (the channel resistance), which are used to realize an adjustable load resistor for the PV generator. Using an external microprocessor, a variableduty PWM signal is generated and fed to the gate drivers, which are then low-pass filtered to supply linear gate voltage ramps to the IGBTs. As the filtered gate voltages exceed the threshold voltage of the IGBTs, the conductivities of the channels increase, forcing the operation point of the PV generator from open circuit to short circuit, and thereby enable the $I-U$ curve measurement. Figure 6 shows (a) the $I$ $U$ curve tracer scheme and (b) the designed tracer prototype.

\section{Climatic Measurements}

The large amount of data recorded continuously to the database from the climatic and radiation sensors can be utilized in various ways. As is commonly known, the available output power of a PV generator depends not only on the received solar radiation, but also on the operation temperature of the modules with a thermal coefficient on the order of $-0.5 \% /{ }^{\circ} \mathrm{C}$. PV module temperature follows radiation changes with delay depending on various heat transfer processes. It also depends on various climatic variables [5]. 


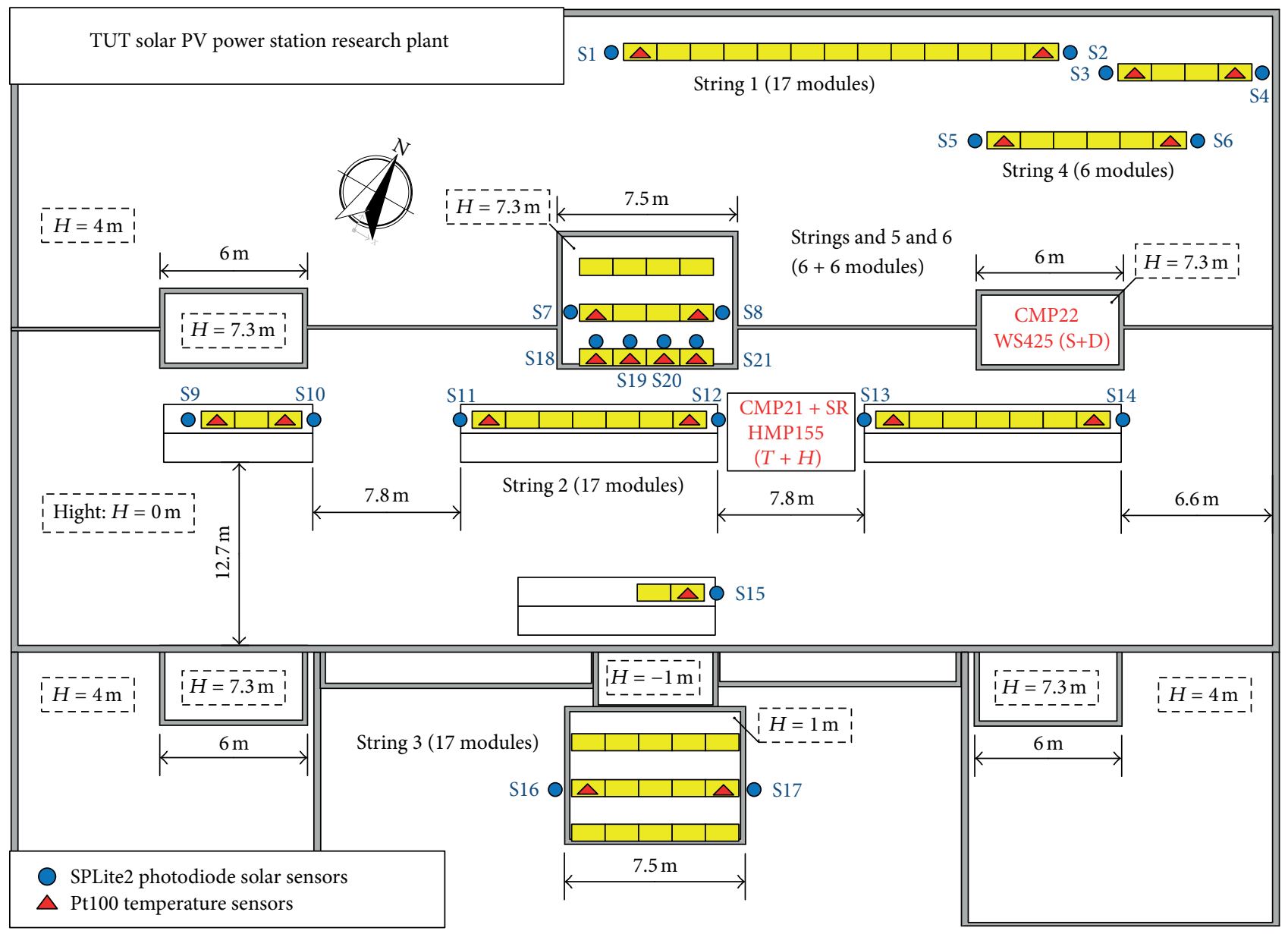

FIGURE 2: Layout scheme of the TUT solar PV power station research plant including its climatic measuring system.

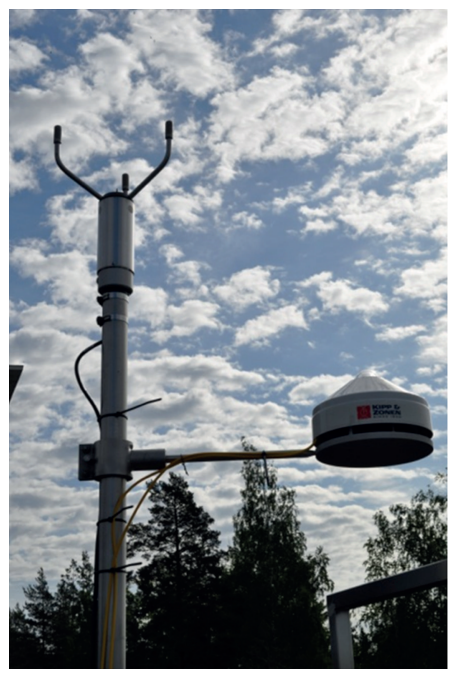

(a)

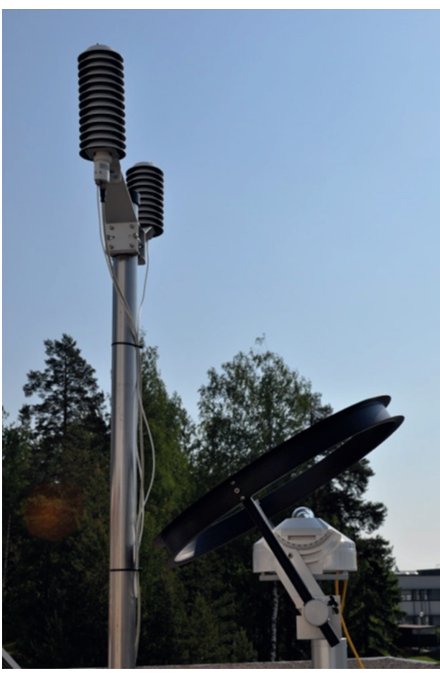

(b)

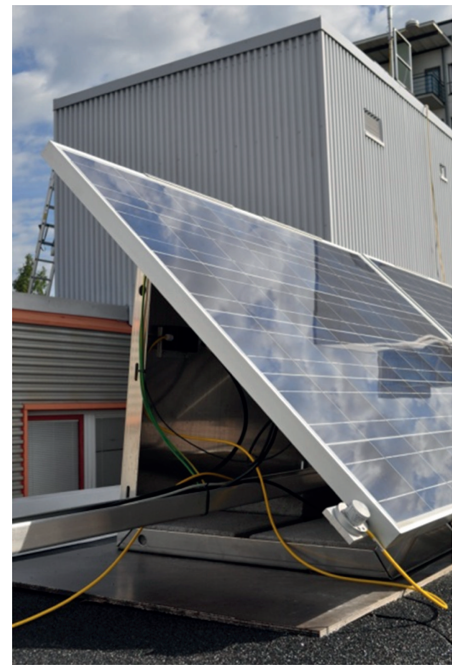

(c)

FIGURE 3: (a) WS425 wind sensor and CMP22 pyranometer, (b) HMP155 sensors with temperature and humidity probes equipped with radiation shields and CMP21 pyranometer combined with the CMC121 shadow ring, and (c) SPLite2 photodiode sensor attached to a PV module. 


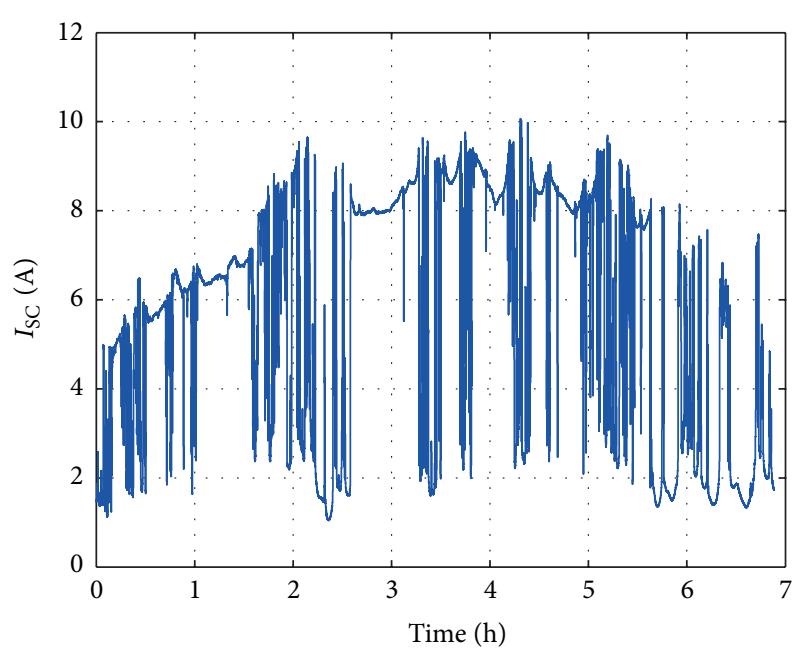

FIGURE 4: Measured $I_{\text {SC }}$ of a single PV module on July 1st, 2010, with a sampling frequency of $25 \mathrm{~Hz}$.

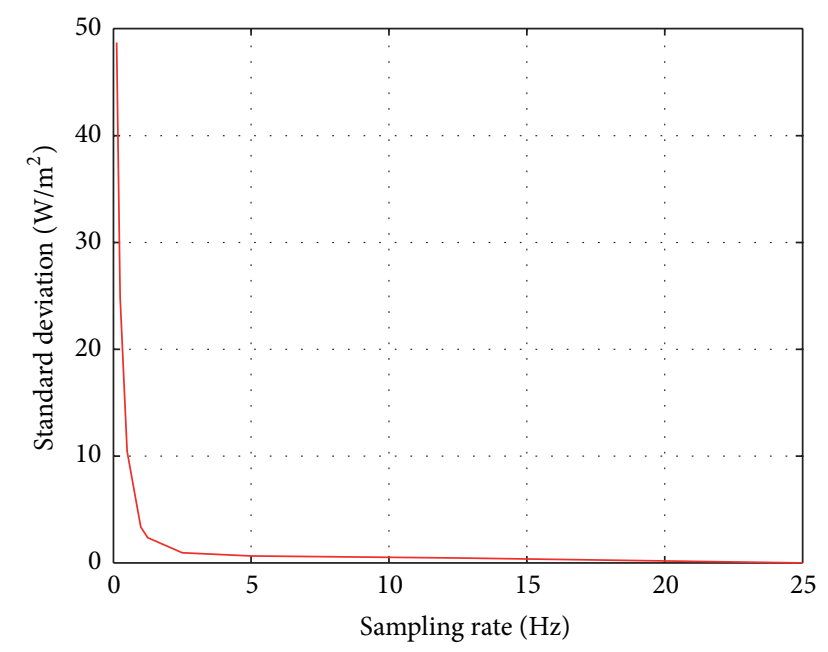

FIGURE 5: Standard deviation error of the incoming solar radiation as a function of the sampling frequency on a single PV module during a period of 7 hours on July 1st, 2010.

Figure 7 shows the measured environmental parameters during a clear sunny day on February 2nd, 2012, for two PV modules of the power plant to illustrate the applicability of the measurements system. A typical strong overall correlation exists between the module temperature and the incoming irradiance. The PV module equipped with sensors S13 (Figure 2) receives solar radiation during the whole day without any major shading, and the module temperature follows radiation changes with certain delay. This delay is directly related to the heat capacity of the module and to the heat transfer between the module and the environment. The PV module equipped with sensors S10 receives solar radiation after sunrise and before sunset, but is shaded by a building structure in the middle of the day so that only diffuse radiation is received. Although incident radiation changes rapidly, changes in temperature are slow due to the thermal mass of the modules. The ambient temperature changed only slightly during the day, having minimal effect on changes in the module temperature. Also humidity stayed practically constant during the day.

Changes in temperature primarily follow changes in irradiance as shown in Figure 7, but temperature fluctuations around eleven o'clock and at half past one do not directly correlate with irradiances. This demonstrates that also other environmental variables affect the module temperature in addition to solar radiation. The higher wind speed before eleven oclock obviously cools down the modules more effectively on the morning than at noon. On the afternoon around half past one o'clock, there is a period of low wind speed causing the heating up of the modules before two o'clock. Also sensor 13 seems to have a better shelter from the wind than sensor 10 during this day due to building structure. Overall, the measured PV module temperature deviates up to $10^{\circ} \mathrm{C}$ from an assumed module temperature based on direct correlation with the incident radiation. Accordingly, an error of $5 \%$ in the estimated electric energy yield of the module can be expected, if only incident solar radiation is used to estimate the module temperature. Therefore, to model the electrical behavior of PV modules and generators reliably, a more advanced dynamic thermal model is needed [5-8].

Sun rises only slightly above the horizon in southern parts of Finland in the midwinter. Therefore, PV modules with a tilt angle of $45^{\circ}$ receive much higher irradiance than pyranometers measuring irradiances on a horizontal surface (Figure 7). Irradiance received by the PV modules increases sharply after the sun is visible for them and decreases as sharply on the afternoon during sunset. Before the sunrise and after the sunset there is a two-hour period of considerable diffuse irradiance. Even on the midday, diffuse radiation constitutes nearly $40 \%$ of global radiation. This is mostly due to reflection of solar radiation from snow. It also explains part of the high irradiance received by the PV modules because they are more exposed to diffuse radiation from the snow than the pyranometers facing the sky.

During summer, the sun sets in Finland only slightly below the horizon for few hours, leaving a weak intensity of light. Daytime solar irradiance is of course higher than that in winter time, but the difference is not dramatic. On the other hand, daytime in summer is up to 20 hours, leading to much higher daily energy yield than that in the winter time. Both global and direct solar radiations received by the $\mathrm{PV}$ modules are considerable high in summer during periods of clear sky. Also diffuse component of radiation is considerable during long periods from sunrise until the sun faces the PV modules and, accordingly, in the evening until sun sets again.

An example of partial shading caused by a building structure on String 2 containing $17 \mathrm{PV}$ modules is shown in Figure 8 . The irradiance profile received by the string indicates that 2 of the $3 \mathrm{PV}$ modules located between sensors S9 and S10 (see Figure 2) are completely shaded by the building structure at 10:30 because sensor S9 (blue line) is shaded all the time and S10 (dashed red line) starts to be shaded after 10:37. The modules located between sensors S11 and S12 are illuminated all the time at a level of $430 \mathrm{~W} / \mathrm{m}^{2}$. Finally, sensor S13 is illuminated at the same level as sensors 


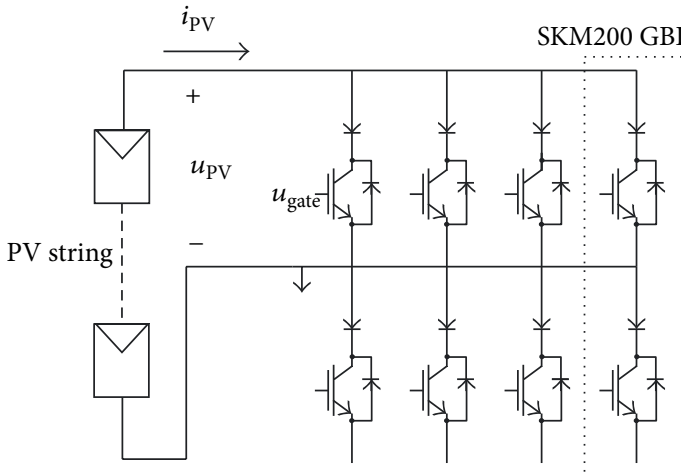

(a)

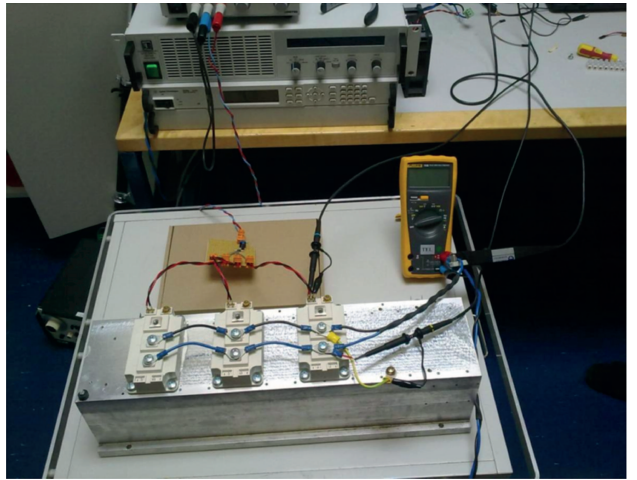

(b)

Figure 6: (a) Scheme of the I-U curve measurement tracer for PV power systems. (b) Picture of the IGBT modules, cooler and power measuring connections.

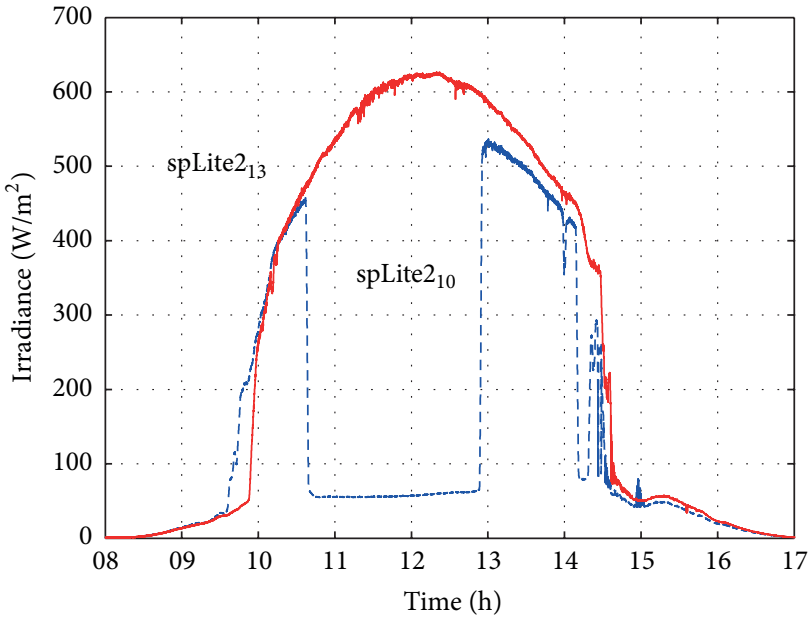

(a)

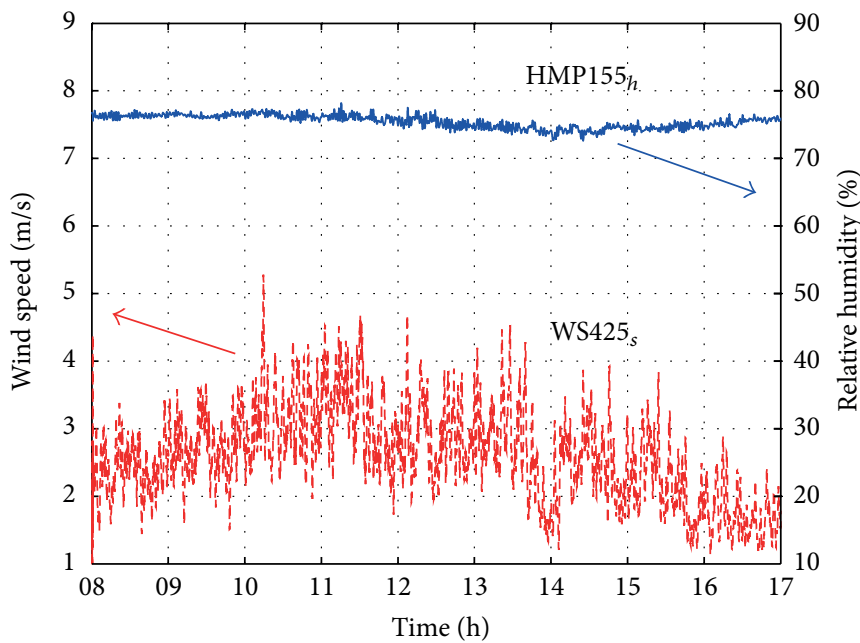

(c)

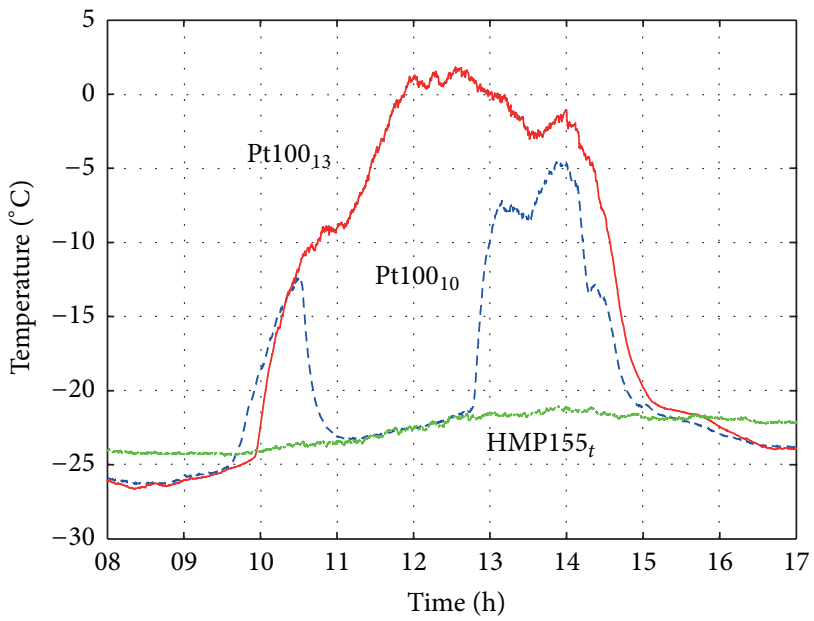

(b)

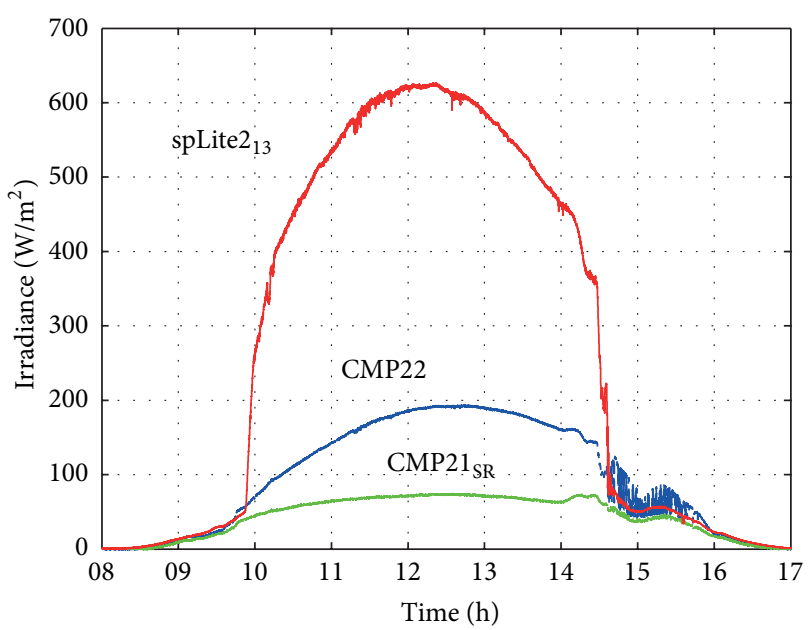

(d)

FIGURE 7: Irradiance and climatic data measured on a sunny day of February 2nd, 2012: (a) irradiances received by two PV modules equipped with irradiance and temperature sensors S10 and S13 (see Figure 2), (b) corresponding module temperatures together with the ambient

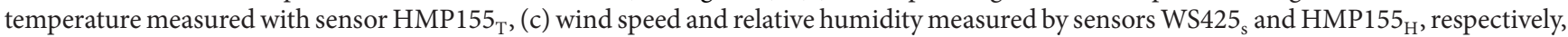
(d) irradiance received by the PV module equipped with sensor S13 together with the global and diffuse irradiances at the research plant measured by pyranometers CMP22 and CMP21, respectively. 


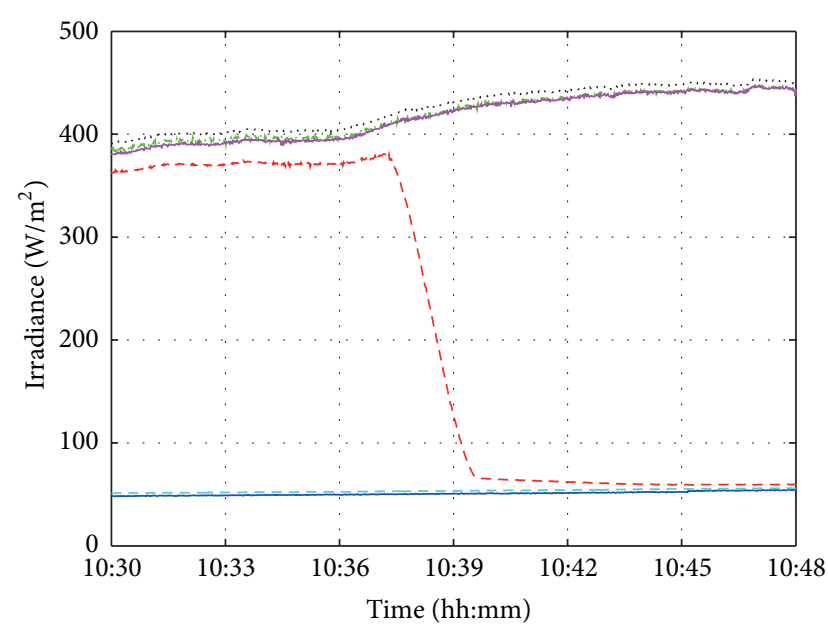

FIGURE 8: Irradiance profile received by String 2 on February 2nd, 2012, during a period of 18 minutes and measured with sensors from S9 to S14 (see Figure 2). Sensors from S9 to S14 correspond to the lines as follows: blue, red dashed, green dash-dotted, black dotted, magenta, and cyan dashed.

S11 and S12, but sensor S14 is shaded all the time. This indicates that parts of the PV modules located between sensors S13 and S14 are shaded due to another building.

The irradiance profile illustrated in Figure 8 demonstrates that the data measured by the climatic measurement system can be used to study systematically the effects of partial shading conditions on the operation of PV generators caused by static building structures. Furthermore, it can be used to discern between the effects due to building structure and moving clouds and to evaluate the energy losses generated by these different shading causes.

\section{Solar Energy Received at TUT Solar PV Power Station Research Plant}

The amount of solar energy collected by a PV module is a function of the incoming solar radiation, the surrounding characteristics, and the module properties, mounting tilt and orientation. In fact, the mounting orientation and tilt of a solar panel strongly affect the amount of collected yield. Therefore, PV modules must be slanted and oriented at the optimum angles to collect the maximum solar energy available in a specific location. The best method to optimize the tilt and orientation of a solar panel is by applying an active sun tracker [19].

Countries in the northern latitudes, for example, Finland, are characterized by low ambient temperatures during most part of the year and high variability of solar radiation levels and trajectory of the sun from summer to winter, which hinders the sizing and optimization of PV generators. Extreme ambient temperatures during winter, snow cover, and ice formation damage mobile parts of trackers, preventing their use. On the other hand, fixed PV module installations will result in overall power losses through the year compared to systems with sun trackers.

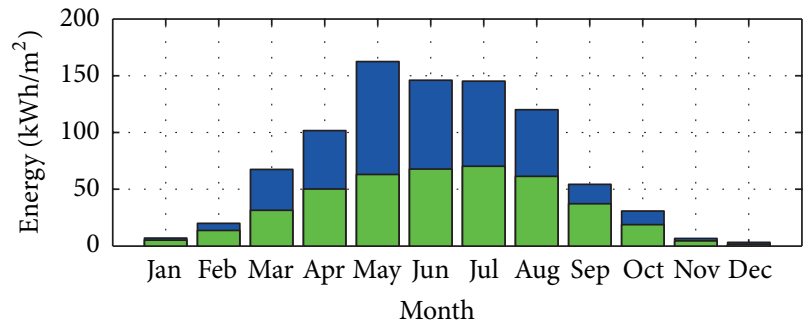

(a)

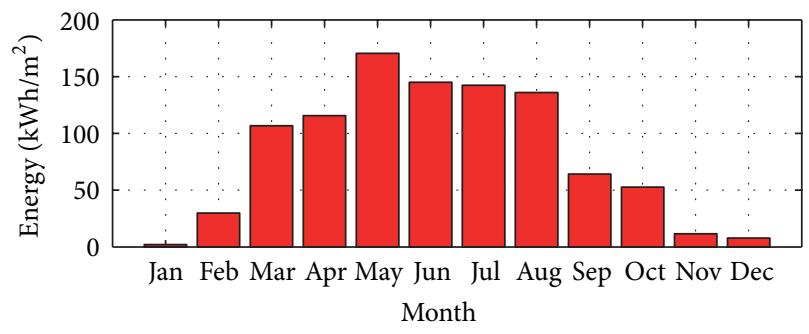

(b)

FIGURE 9: Monthly solar energy received at the TUT solar PV power station research plant during its first year of operation (August 2011 to July 2012): the blue bars on top graph correspond to the global solar energy received on the horizontal plane (measured by pyranometer CMP22), the green bars on top graph represent the diffuse solar energy on the horizontal plane (measured by pyranometer CMP21 combined with the shadow ring) and the red bars at the bottom graph correspond to the global solar energy received on the plane of modules (measured by the SPLite2 sensor S13).

TUT solar PV power station research plant is a fixed installation optimized for overall operation during the year. PV modules are mounted in line with the buildings oriented $26^{\circ}$ east of due south with a tilt angle of $45^{\circ}$ from the horizontal plane. The optimal module inclination angles by month for locations with Tampere latitude are included in Table 2. Figure 9 illustrates the monthly global and diffuse solar energy received on a horizontal plane and the monthly global solar energy on PV modules from August 2011 to July 2012.

In the top graph of Figure 9, the levels of monthly global solar energy received on the horizontal plane in Tampere vary from $3.14 \mathrm{kWh} / \mathrm{m}^{2}$, in December, to $160.50 \mathrm{kWh} / \mathrm{m}^{2}$, in May, in line with [20]. The year 2012 has been particularly overcast with small amount of days with clear sky in spring and summer. This can be confirmed by comparing yearly average of $909.35 \mathrm{kWh} / \mathrm{m}^{2}$ by [20] with the $864.64 \mathrm{kWh} / \mathrm{m}^{2}$ measured in TUT's research plant during its first year of operation. Nonetheless, such levels of yearly solar energy do not diverge excessively with respect to the radiation levels received in northern Germany. The diffuse component of solar radiation on the horizontal plane indicates that months from September to February are mostly cloudy as they present large ratios of diffuse to global solar radiation. The remaining months from March to August show higher values of global solar energy received on the horizontal plane 
TABLE 2: Optimal monthly module inclination angles from the horizontal plane for TUT location according to [20].

\begin{tabular}{cccccccccccc}
\hline Jan & Feb & Mar & Apr & May & Jun & Jul & Aug & Sep & Oct & Nov & Dec \\
\hline $78^{\circ}$ & $73^{\circ}$ & $59^{\circ}$ & $44^{\circ}$ & $30^{\circ}$ & $22^{\circ}$ & $25^{\circ}$ & $35^{\circ}$ & $50^{\circ}$ & $63^{\circ}$ & $72^{\circ}$ & $80^{\circ}$ \\
\hline
\end{tabular}

having maximum on summer time due to the wider path of sun through the sky. In Tampere, on December, March, and June 21 sts the sun rises at $38^{\circ}, 92^{\circ}$, and $148^{\circ}$ east of due south and sets at $38^{\circ}, 92^{\circ}$, and $148^{\circ}$ west of due south, respectively, resulting in much longer daytimes in summer than in winter. Also the relative part of diffuse radiation in the global radiation is smaller during summer months than that in winter, and sunny days are more common.

The bottom graph of Figure 9 illustrates the global solar energy received on a plane in line with the PV modules. The levels of solar energy measured from November to February are particularly low, especially in January when the received solar energy on the modules is lower than that on the horizontal plane. This phenomenon is caused by the snow covering the PV modules and photodiodebased SPLite2 sensors attached to them during most of this period. The pyranometers CMP22 and CMP21 were clear from snow since they are heated to prevent snow piling on the domes. Additionally, both pyranometers are located at a higher level than the PV modules (see Figure 3), ensuring that they were not covered by snow piles during the measuring period. The months of March, April, September, and October present higher values of solar energy received on the plane of modules with respect to values on the horizontal plane. This is consistent with the fact that the modules tilt is closer to the optimum angles for those months (Table 2). The summer months, May, June, July, and August, present the largest values of solar energy received. However, in June and July solar energy received on the tilted plane was 1.02 and $2.85 \mathrm{kWh} / \mathrm{m}^{2}$ less than that on the horizontal plane, respectively. This can be explained by the wide path of the sun through the sky during summer. Figure 10 demonstrates this matter explicitly. The PV modules receive much higher solar radiation levels in the middle of the day than the horizontal plane. However, the irradiance received by the PV modules decreases rapidly after three o'clock, while the global irradiance on the horizontal plane decreases more smoothly until nine oclock in the evening.

Figures 9 and 10 imply that the use of sun-tracking systems adjusting both inclination and orientation of PV modules would highly enhance the power produced by PV generators located in northern latitudes. Actually part of the direct solar radiation is lost totally on summer time with fixed installations because in the morning after sunrise and in the evening before sunset sun shines only on the backsides of the modules. TUT PV modules are oriented $26^{\circ}$ east of due south, and, therefore, PV modules lose the direct part of solar radiation during evening hours. In fact, extrapolation of the solar energy levels received using a sun-tracking system suggests that they would reach the levels of solar energy received by fixed PV systems in southern Germany.

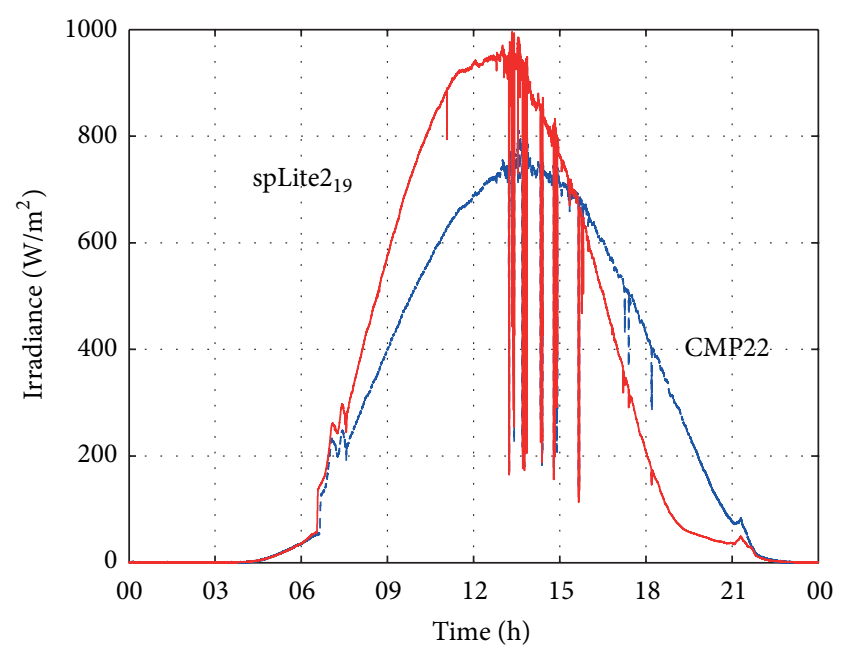

FIGURE 10: Solar radiation on the plane of PV modules measured by sensor S19 (red line) and on the horizontal plane measured by pyranometer CMP22 (blue dashed line) on July 22nd, 2011.

\section{Effects of Partial Shading and Reflections Caused by Building Structures and Snow}

The TUT solar PV power station research plant provides excellent conditions to study the operation PV power plants under varying climatic and environmental conditions. Especially the comprehensive measurements around the power plant with high sampling frequency make it possible to study even the fastest phenomena affection to the electrical operation of the plant. To demonstrate these abilities the effects of partial shading and reflections of solar radiation due to building structures and snow on PV modules and strings have been analyzed by means of the measured electrical $I-U$ and $P-U$ characteristics (Figures 11 and 12).

The effect of partial shading on the electrical characteristics of a single PV module is clearly seen in Figure 11, where the operation under partial shading conditions on February $3 \mathrm{rd}, 2012$, is compared to the operation under homogeneous conditions on August 31st, 2011. Table 3 includes the most important environmental parameter values at the instant when the electrical measurements were taken. In this case, the partial shading is caused by a thin layer of ice covering the lower row of PV cells and, thereby, filtering the solar radiation received by them. While the rest of cells on upper rows receive sunlight directly at an irradiance level of $430 \mathrm{~W} / \mathrm{m}^{2}$, the row of cells covered by ice received approximately two-thirds of the incoming irradiance.

Operation of the PV module under 2 different irradiance levels leads to two local MPPs in contrast with the typical 
TABLE 3: Environmental conditions of the PV module equipped with radiation and temperature sensors $\mathrm{S} 19$ at the moments, when curves in Figure 11 were measured.

\begin{tabular}{lccc}
\hline Date & Time & $\begin{array}{c}\text { Irradiance } \\
\left(\mathrm{W} / \mathrm{m}^{2}\right)\end{array}$ & $\begin{array}{c}\text { Mod. temp. } \\
\left({ }^{\circ} \mathrm{C}\right)\end{array}$ \\
\hline August 31st, 2011 & $12: 04$ & 450.8 & 32.42 \\
February 3rd, 2012 & $11: 19$ & 429.5 & -12.10 \\
\hline
\end{tabular}

operation under homogeneous irradiance level, which produces one unique global MPP as can be seen in Figure 11. Disparity between the open circuit voltages of the two measurements is due to the different operating temperatures. This textbook level example demonstrates how simple partial shading condition and difference in ambient temperature are seen on a module level in real measurements. This kind of shading is typically caused also by building structures, whose cases can be analyzed systematically from the measured data.

To provide a more realistic view on the effects of partial shading on the operation of PV power plants, the operation of strings of 6 series-connected PV modules during autumn on September 28th, 2011, and in winter on February 3rd, 2012, is shown in Figure 12. Table 4 includes the most important environmental parameter values at the instant when the electrical measurements were taken. The measured $I-U$ and $P-U$ characteristics of String 4 (see Figure 2) are measured under homogeneous irradiance conditions during the autumn day at 09:36. Thus the electrical characteristics of the PV string are smooth with one global MPP. The electrical characteristics of String 5 (see Figure 2) are measured under varying irradiance conditions during the winter day at 12:08. They clearly show several local MPPs which could lead to incorrect operation of a MPPT algorithm in a PV inverter. The reason behind these multiple local MPPs is, again, a thin layer of ice formed in the lower part of the PV modules, as well as reflections off the snow.

In the PV modules, a bypass diode is connected in parallel with a string of $18 \mathrm{PV}$ cells (2 horizontal rows of cells) to protect them from overheating. String 5 consists of 6 PV modules, which had ice covering at least part of their lower rows of cells on February 3rd 2012. Based on Figure 12, onethird of PV cells seem to be shaded by ice receiving the same irradiance of approximately $290 \mathrm{~W} / \mathrm{m}^{2}$ and producing a current of $2 \mathrm{~A}$ (see the $I-U$ curve in Figure 13). Accordingly, another one-third of PV cells are nonshaded receiving an irradiance of approximately $450 \mathrm{~W} / \mathrm{m}^{2}$ and producing a current close to $3.5 \mathrm{~A}$. These cells are most probably on the upper parts of the modules. The last one-third of PV cells receive varying amounts of irradiance between 290 and $450 \mathrm{~W} / \mathrm{m}^{2}$ due to smaller shading than the lower rows of cells. Therefore, several local MPPs are observed in the $P-U$ curve in Figure 12 at voltages between 90 and $130 \mathrm{~V}$. These kinds of conditions can cause major problems to the proper operation of PV inverters.

As a third demonstration on the potential of the TUT solar PV power station research plant, the operation of PV strings was analyzed under partial shading conditions caused by building structures. As explained in Section 2, the location of the PV modules and strings in the research plant was carefully selected for permitting this type of measurements. However, this phenomenon only takes place during clear sky days in periods of the year in which the trajectory of the sun is only slightly above the horizon, that is, late autumn, winter, and early spring in Finland. Therefore, measurements on December 4th, 2012, for string 4 were used in this study.

String 4, which is composed of $6 \mathrm{PV}$ modules connected in series in a row, was cleaned from snow, and electrical measurements were taken for 5 different partial shading conditions. Table 5 comprises the irradiances and module temperatures at both ends of String 4 measured by sensors S5 and S6 at the moments when the electrical measurements were taken. Measurements 1 to 4 correspond to operation under partial shading conditions of the PV string with 2, 3,4 , and 5 nonshaded modules, respectively. Measurement 5 shows the operation of the string under homogenous conditions. The operational conditions of String 4 during measurements 1 and 4 with 2 and 5 nonshaded PV modules are shown in Figure 13.

Irradiances measured at both ends of String 4 around the noon in December 4th 2012 are shown in Figure 14. Irradiances measured by sensor $\mathrm{S} 5$ are typical clear sky values for that time of year in Finland showing that the left end of String 4 is nonshaded during the whole measurement period. On the other hand, irradiance value measured by sensor S6 stays constant around $32 \mathrm{~W} / \mathrm{m}^{2}$ under the shadow of the building until 12:55 h. After that the whole string is nonshaded for a while and measurement 5 can be considered to be done under homogenous irradiance condition for the whole string. Solar radiation measured by sensors S5 and S6 during measurement 5 can be considered to correspond to homogenous irradiance conditions, in practice, since the small difference between them can be due to, for example, slightly different mounting angles of the irradiance sensors. The smooth shapes of $I-U$ and $P-U$ curves of measurement 5 in Figure 15 support this assumption.

The module temperatures measured by the temperature sensors S5 and S6 are in line with the measured irradiance trends (Table 5). Solar radiation is heating up the PV modules by almost $20^{\circ} \mathrm{C}$ according to the temperature difference of PV modules at both ends of the string during partial shading. Temperature of the last PV module on the left in Figure 13 measured by sensor $\mathrm{S} 6$ rose over $10^{\circ} \mathrm{C}$ before it was fully nonshaded at the time of measurement 5. It took almost half an hour for the edge of the shadow to pass the module. During this time the direct solar radiation heated the PV module gradually, before it was fully under direct solar radiation.

The effect of partial shading on String 4 is illustrated in Figure 15 by the $I-U$ and $P-U$ characteristics for 4 partial shading conditions along with one homogenous irradiance condition. Under partial shading conditions caused by building structures, each of the shaded $I-U$ and $P-U$ curves can be divided in two different areas. In the first area, bypass diodes protecting groups of shaded cells are conducting and shorting out the circuits of groups of $18 \mathrm{PV}$ cells and thus eliminating effects of shading like possible hot spots. In the second area, higher voltages appear since the bypass diodes 


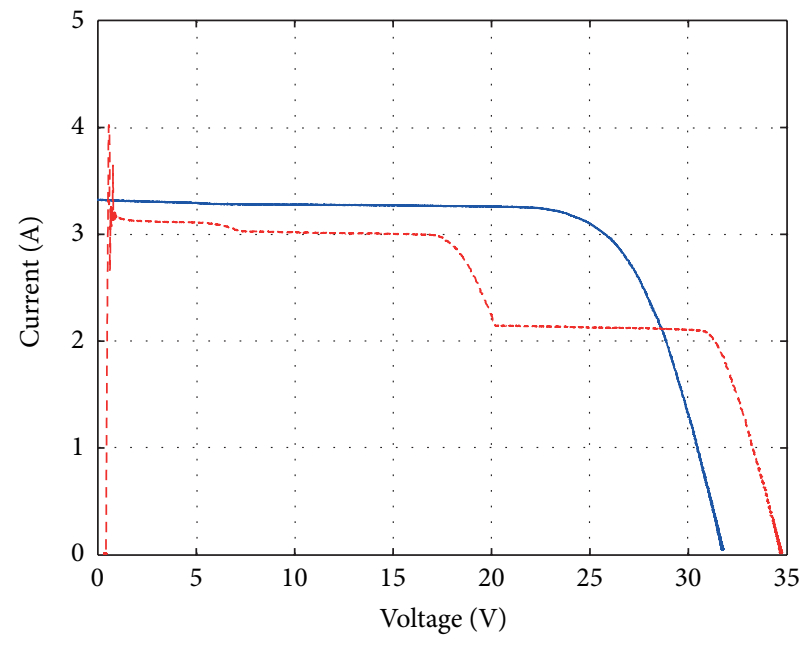

(a)

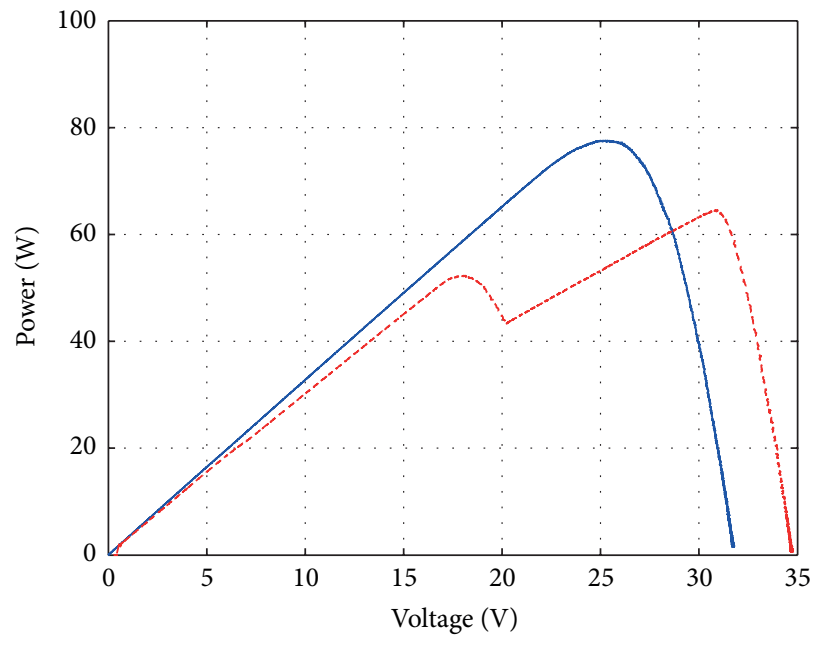

(b)

FIGURE 11: Measured (a) I-U and (b) P-U characteristics of the PV module equipped with irradiance and temperature sensor S19 under homogeneous irradiance on August 31st, 2011, at 12:04 (blue lines) and under partial shading conditions on February 3rd, 2012, at 11:19 (reddashed lines).

TABLE 4: Environmental conditions of the PV strings on September 28th, 2011, measured with sensors S5 and S6 located at both ends of String 4, and on February 3rd, 2012, measured with sensors S7 and S8 located at both ends of String 5 at the moments when the curves in Figure 12 were measured.

\begin{tabular}{lcccccc}
\hline & \multicolumn{2}{c}{ September 28th 2011} & & \multicolumn{2}{c}{ February 3rd 2012 } \\
Sensor & Time & $\begin{array}{c}\text { Irradiance } \\
\left(\mathrm{W} / \mathrm{m}^{2}\right)\end{array}$ & $\begin{array}{c}\text { Mod. } \\
\text { temp. } \\
\left({ }^{\circ} \mathrm{C}\right)\end{array}$ & Sensor & Time & $\begin{array}{c}\text { Irradiance } \\
\left(\mathrm{W} / \mathrm{m}^{2}\right)\end{array}$ \\
\hline S5 & $09: 36 \mathrm{~h}$ & 568.1 & 25.09 & $\mathrm{~S} 7$ & $12: 08 \mathrm{~h}$ & 436.7 \\
S6 & $09: 36 \mathrm{~h}$ & 594.9 & 26.58 & $\mathrm{~S} 8$ & $12: 08 \mathrm{~h}$ & 443.4 \\
\hline
\end{tabular}

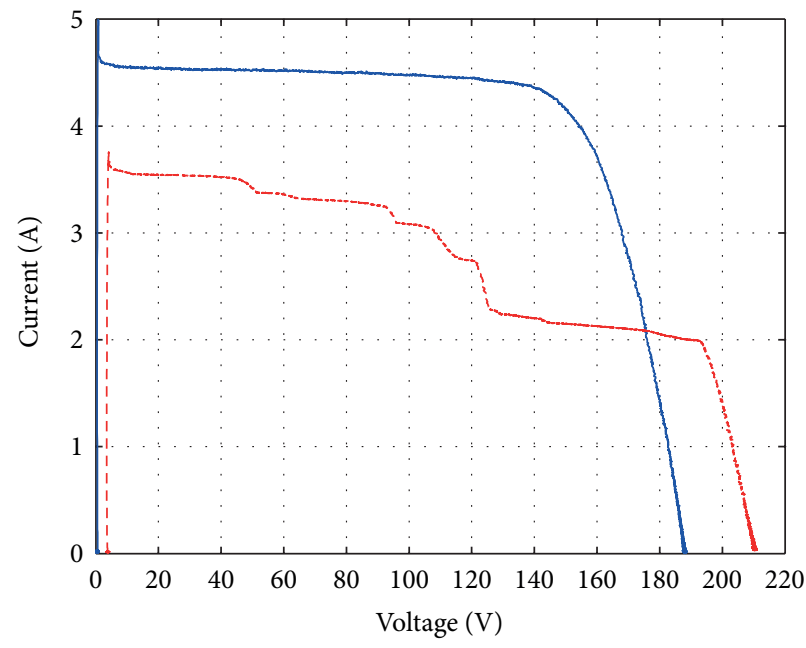

(a)

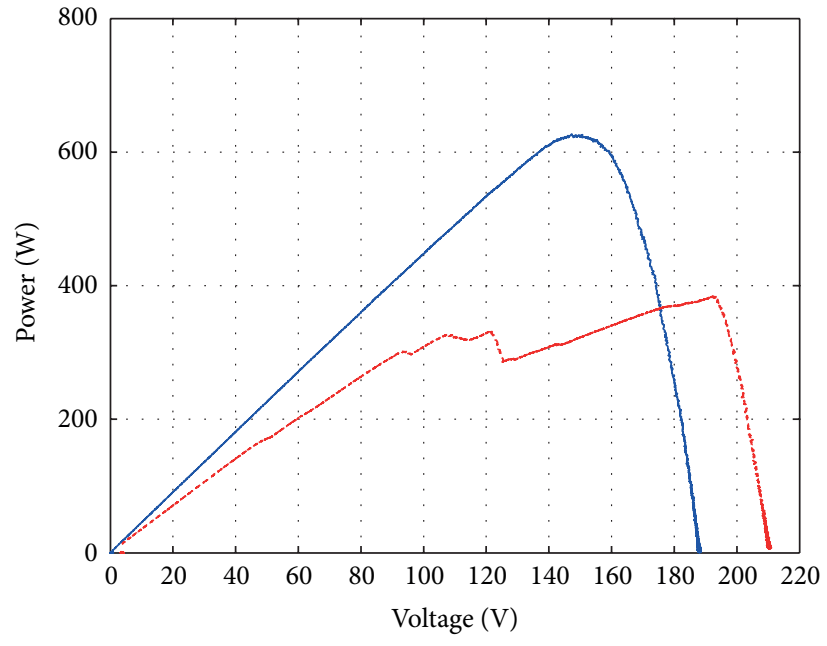

(b)

FIgURE 12: (a) $I-U$ and (b) P-U characteristics of PV strings of 6 series-connected PV modules. Characteristics of String 4 were measured on September 28th, 2011, under homogeneous irradiance conditions at 09:36 (blue lines) and of String 5 on February 3rd, 2012, under partial shading conditions at 12:08 (red dashed lines). 


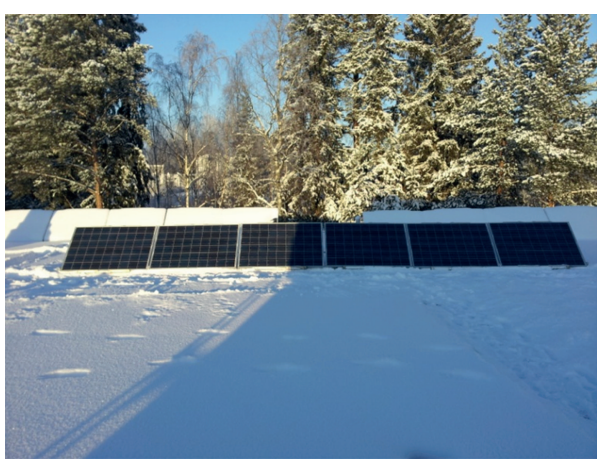

(a)

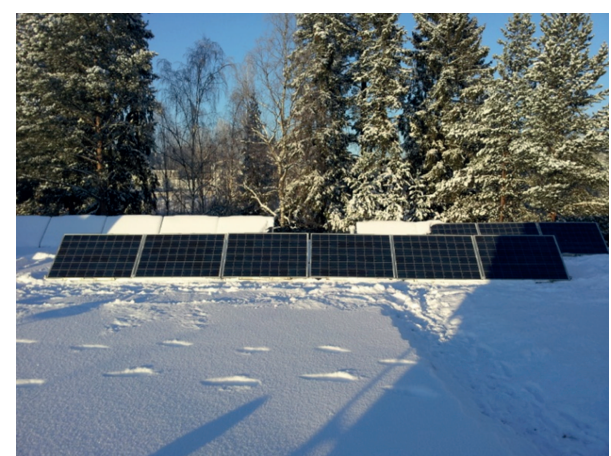

(b)

FIGURE 13: Figures of the operational conditions of String 4 under partial shading conditions caused by a building structure during the electrical measurements on December 4th, 2012: (a) conditions of measurement 1 with 2 nonshaded PV modules and 4 fully or partially shaded PV modules, (b) conditions of measurement 4 with 5 nonshaded PV modules and 1 partially-shaded PV module.

TABLE 5: Irradiances received by the PV string and module temperatures on December 4th, 2012, measured with sensors S5 and S6 located at both ends of String 4 at the moments when curves in Figure 15 were measured.

\begin{tabular}{|c|c|c|c|c|c|}
\hline \multirow{3}{*}{ Measurement } & \multirow{3}{*}{ Time } & \multicolumn{4}{|c|}{ Sensor } \\
\hline & & \multicolumn{2}{|c|}{ S5 } & \multicolumn{2}{|c|}{ S6 } \\
\hline & & $\begin{array}{l}\text { Irradiance } \\
\left(\mathrm{W} / \mathrm{m}^{2}\right)\end{array}$ & $\begin{array}{l}\text { Mod. } \\
\text { temp. } \\
\left({ }^{\circ} \mathrm{C}\right)\end{array}$ & $\begin{array}{l}\text { Irradiance } \\
\left(\mathrm{W} / \mathrm{m}^{2}\right)\end{array}$ & $\begin{array}{l}\text { Mod. } \\
\text { temp. } \\
\left({ }^{\circ} \mathrm{C}\right)\end{array}$ \\
\hline 1 & $11: 24 \mathrm{~h}$ & 425.9 & -1.58 & 30.5 & -17.42 \\
\hline 2 & $11: 37 \mathrm{~h}$ & 439.9 & 0.73 & 31.2 & -17.37 \\
\hline 3 & $12: 05 \mathrm{~h}$ & 438.4 & 3.71 & 32.5 & -16.97 \\
\hline 4 & $12: 31 \mathrm{~h}$ & 424.0 & 3.19 & 33.3 & -16.48 \\
\hline 5 & $12: 57 \mathrm{~h}$ & 386.6 & 1.93 & 353.8 & -5.85 \\
\hline
\end{tabular}

protecting the groups of nonshaded cells are reverse biased and the characteristic of the string is dominated by the series-connected shaded cells. The voltage levels at the local maximum power points at low voltages in measurements 1,23 , and 4 are approximately 50,80, 105, and $140 \mathrm{~V}$, respectively. The voltages of the local MPPs at high voltages are roughly between 170 and $195 \mathrm{~V}$ for the studied partial shading conditions.

Several maximum power point tracking algorithms search for MPPs around $80 \%$ of open-circuit voltage, that is, around $160 \mathrm{~V}$ under the studied operating conditions. It would result in incorrect operation of the PV inverter in the local MPP at high voltages instead of the global MPP at lower voltages leading to major power losses. Maximum power of local MPPs at high voltages is between 50 and $70 \mathrm{~W}$, but the power of the local MPP at low voltages goes up to $400 \mathrm{~W}$ or so. In the studied case the partial shading condition leading to the occurrence of two local maxima in $P$ $U$ characteristics lasts for close to 2.5 hours. If an inverter has operated the whole period in the local MPP at high voltages due to a simple voltage reference, as described above, losses of produced power could have been close to $0.5 \mathrm{kWh}$ for the

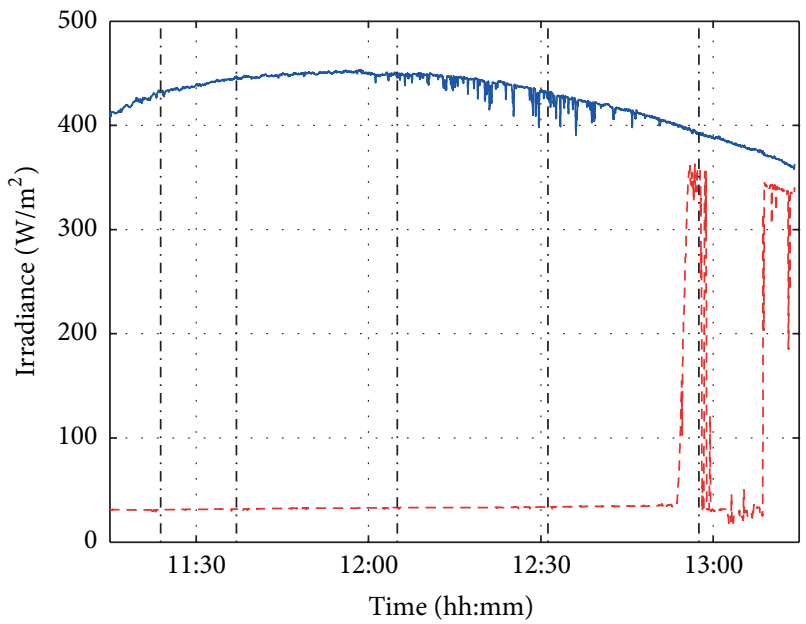

FIGURE 14: Irradiance profile received by String 4 during the electrical measurements of Figure 15 measured by sensors S5 (blue line) and S6 (red-dashed line) on December 4th, 2012. The moments when the electrical measurements were taken are marked with vertical dash-dotted lines.

studied string of only $6 \mathrm{PV}$ modules. The produced power would have been just over $0.1 \mathrm{kWh}$.

The collected data from the environmental measurement system of the PV power plant enables systematic studies of the electrical behavior of the power plant, for example, under shading due to building or clouds. Simulation tools are under development to analyze these kinds of issues during periods up to years.

\section{Conclusions}

This paper describes the TUT Solar PV Power Station Research Plant installed on the rooftop of the Department of Electrical Engineering at the Tampere University of Technology jointly with its climatic, electrical, and data-acquisition systems. The layout of the PV modules and strings, climatic measurements, data acquisition, and database are designed 


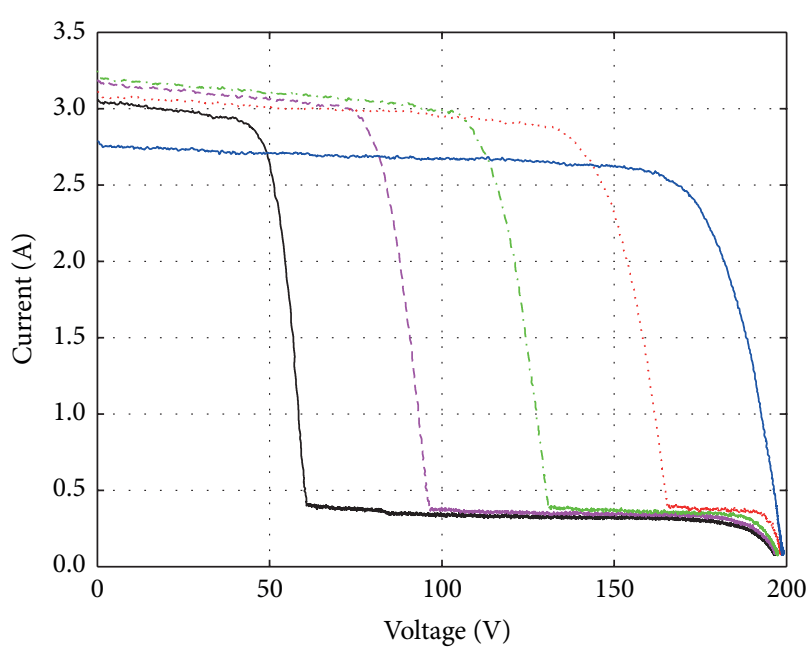

(a)

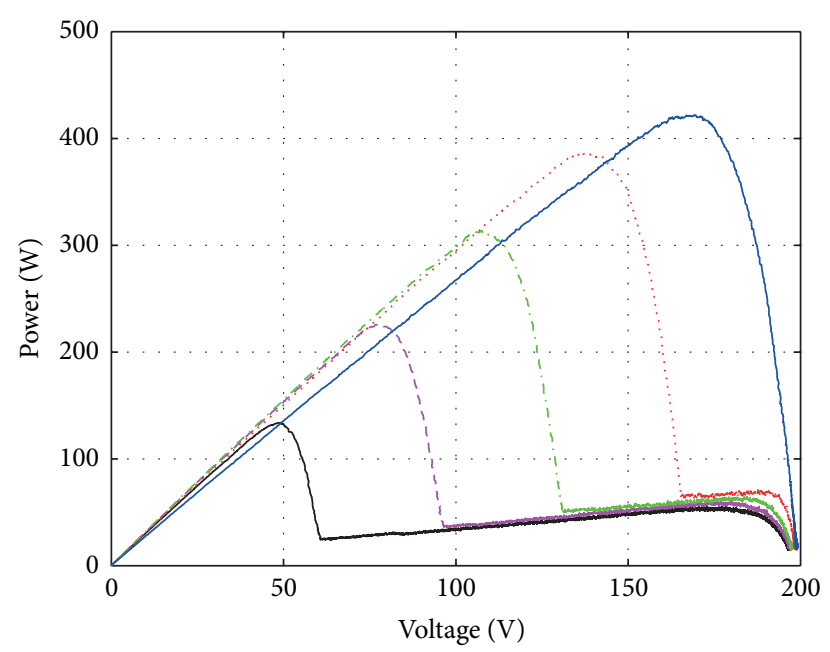

(b)

Figure 15: (a) $I-U$ and (b) $P$ - $U$ characteristics of String 4 (see Figure 2) of 6 series-connected PV modules measured under partial shading conditions on December 4th, 2012. Irradiances and module temperatures measured with sensors S5 and S6 at the corresponding moments are presented in Table 4. Measurements from 1 to 5 correspond to the lines as follows: black, magenta dashed, green dash-dotted, red dotted, and blue.

for studying the operation of PV systems under nonuniform and rapidly varying operational conditions. Sampling frequency of $10 \mathrm{~Hz}$ is shown to be sufficient to detect even the fastest phenomena being related to power generation with PV power plants.

Strong overall correlation between the PV module temperature and the incoming irradiance has been observed in the measurements, as expected. However, the experimental results also demonstrate that irradiance does not alone describe adequately the thermal behavior of PV modules. There is a need to develop a more advanced dynamic thermal model for predicting module temperature more accurately than is possible by existing models. It was shown that ice covering part of the PV modules and reflections due to the snow surrounding the modules had a major effect on the electrical behavior of PV strings. They created multiple local maximum power points in measured electrical characteristics of PV modules and strings of series-connected modules. Operation of PV strings under partial shading caused by a building structure generates power characteristic curves with two local maximum power points in good agreement with earlier theoretical findings. These kinds of shading conditions will cause major problems to conventional maximum power point tracking algorithms.

\section{References}

[1] European Photovoltaic Industry Association (EPIA), "Solar photovoltaicscompeting in the energy sector-on the road to competitiveness," September 2011, http://www.epia.org/index .php?eID=tx_nawsecuredl\&u=0\&file=/uploads/tx_epiapublications/Competing_Full_Report.pdf\&t=1377285583\&hash=c74000f30f1171e54ff12bbe83caaf5396006fldcaaf5396006fld.

[2] A. Mäki and S. Valkealahti, "Operation of long series connected silicon-based photovoltaic module strings and parallel connected short strings under partial shading conditions," in Proceedings of the 26th European Photovoltaic Solar Energy Conference and Exhibition (EUPVSEC '11), pp. 4227-4232, 2011.

[3] L. Sandrolini, M. Artioli, and U. Reggiani, "Numerical method for the extraction of photovoltaic module double-diode model parameters through cluster analysis," Applied Energy, vol. 87, no. 2, pp. 442-451, 2010.

[4] S. Nagae, M. Toda, T. Minemoto, H. Takakura, and Y. Hamakawa, "Evaluation of the impact of solar spectrum and temperature variations on output power of silicon-based photovoltaic modules," Solar Energy Materials and Solar Cells, vol. 90, no. 20, pp. 3568-3575, 2006.

[5] A. D. Jones and C. P. Underwood, "A thermal model for photovoltaic systems," Solar Energy, vol. 70, no. 4, pp. 349-359, 2001.

[6] M. Mattei, G. Notton, C. Cristofari, M. Muselli, and P. Poggi, "Calculation of the polycrystalline PV module temperature using a simple method of energy balance," Renewable Energy, vol. 31, no. 4, pp. 553-567, 2006.

[7] E. Skoplaki, A. G. Boudouvis, and J. A. Palyvos, "A simple correlation for the operating temperature of photovoltaic modules of arbitrary mounting," Solar Energy Materials and Solar Cells, vol. 92, no. 11, pp. 1393-1402, 2008.

[8] S. Armstrong and W. G. Hurley, "A thermal model for photovoltaic panels under varying atmospheric conditions," Applied Thermal Engineering, vol. 30, no. 11-12, pp. 1488-1495, 2010.

[9] A. Woyte, J. Nijs, and R. Belmans, "Partial shadowing of photovoltaic arrays with different system configurations: literature review and field test results," Solar Energy, vol. 74, no. 3, pp. 217233, 2003.

[10] M. García, J. M. Maruri, L. Marroyo, E. Lorenzo, and M. Pérez, "Partial shadowing, MPPT performance and inverter configurations: observations at tracking PV plants," Progress in Photovoltaics: Research and Applications, vol. 16, no. 6, pp. 529536, 2008. 
[11] C. E. Chamberlin, P. Lehman, J. Zoellick, and G. Pauletto, "Effects of mismatch losses in photovoltaic arrays," Solar Energy, vol. 54, no. 3, pp. 165-171, 1995.

[12] N. D. Kaushika and A. K. Rai, "An investigation of mismatch losses in solar photovoltaic cell networks," Energy, vol. 32, no. 5, pp. 755-759, 2007.

[13] E. Karatepe, M. Boztepe, and M. Çolak, "Development of a suitable model for characterizing photovoltaic arrays with shaded solar cells," Solar Energy, vol. 81, no. 8, pp. 977-992, 2007.

[14] G. Walker, "Evaluating MPPT converter topologies using a matlab PV model," Journal of Electrical and Electronics Engineering, vol. 21, no. 1, pp. 49-55, 2001.

[15] A. Mäki, S. Valkealahti, and J. Leppäaho, "Operation of seriesconnected silicon-based photovoltaic modules under partial shading conditions," Progress in Photovoltaics: Research and Applications, vol. 20, no. 3, pp. 298-309, 2012.

[16] E. V. Paraskevadaki and S. A. Papathanassiou, "Evaluation of MPP voltage and power of mc-Si PV modules in partial shading conditions," IEEE Transactions on Energy Conversion, vol. 26, no. 3, pp. 923-932, 2011.

[17] A. Mäki and S. Valkealahti, "Power losses in long string and parallel-connected short strings of series-connected siliconbased photovoltaic modules due to partial shading conditions," IEEE Transactions on Energy Conversion, vol. 27, no. 1, pp. 173183, 2012.

[18] World Meteorological Organization (WMO), Guide to Meteorological Instruments and Methods of Observation, 2008, http://www.wmo.int/pages/prog/www/IMOP/CIMO-Guide .html.

[19] T. Khatib, A. Mohamed, and K. Sopian, "Optimization of a $\mathrm{PV} /$ wind micro-grid for rural housing electrification using a hybrid iterative/genetic algorithm: case study of Kuala Terengganu, Malaysia," Energy and Buildings, vol. 47, pp. 321-331, 2012.

[20] "Free Online Estimation of the Solar Irradiance and Ambient Temperature in Any European and African Location," February 2012, http://re.jrc.ec.europa.eu/pvgis/apps4/pvest.php. 

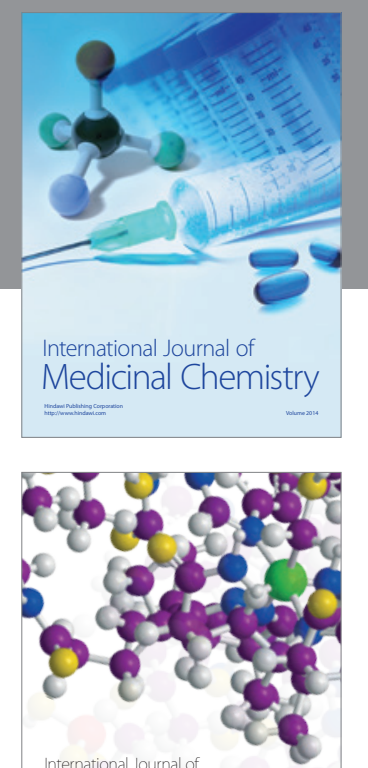

\section{Carbohydrate} Chemistry

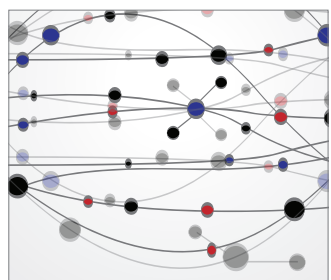

The Scientific World Journal
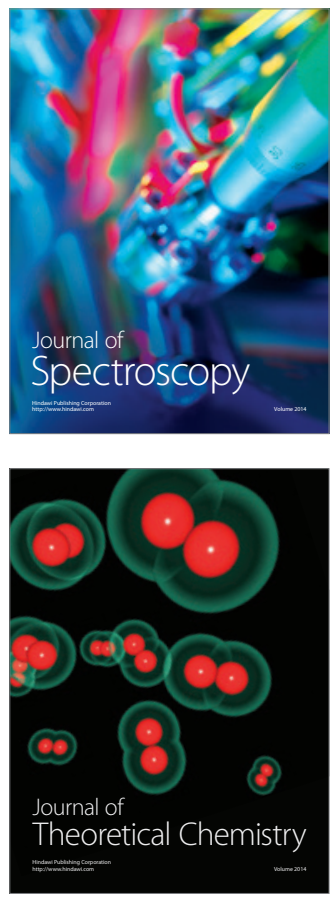
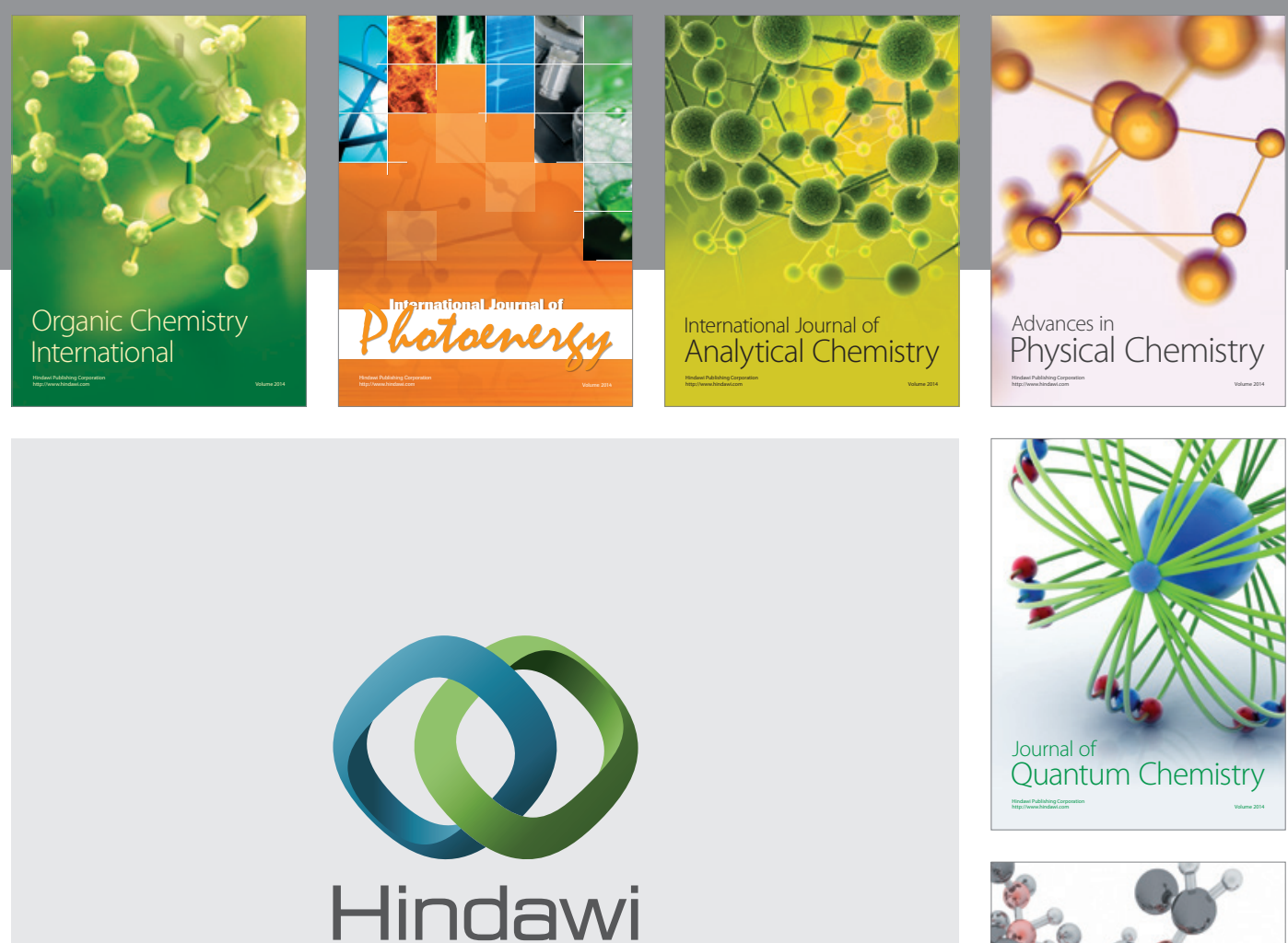

Submit your manuscripts at

http://www.hindawi.com

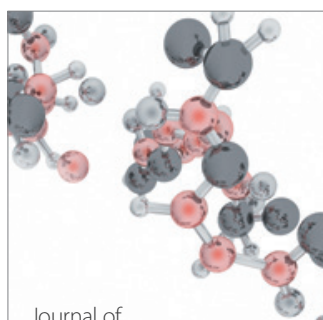

Analytical Methods

in Chemistry

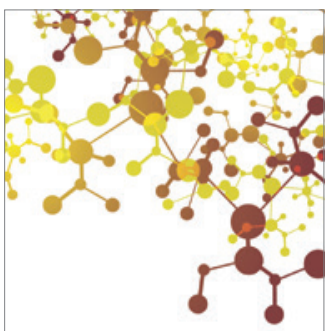

Journal of

Applied Chemistry

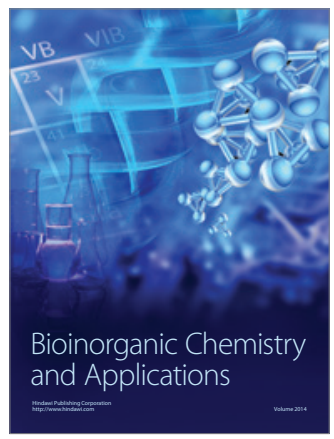

Inorganic Chemistry
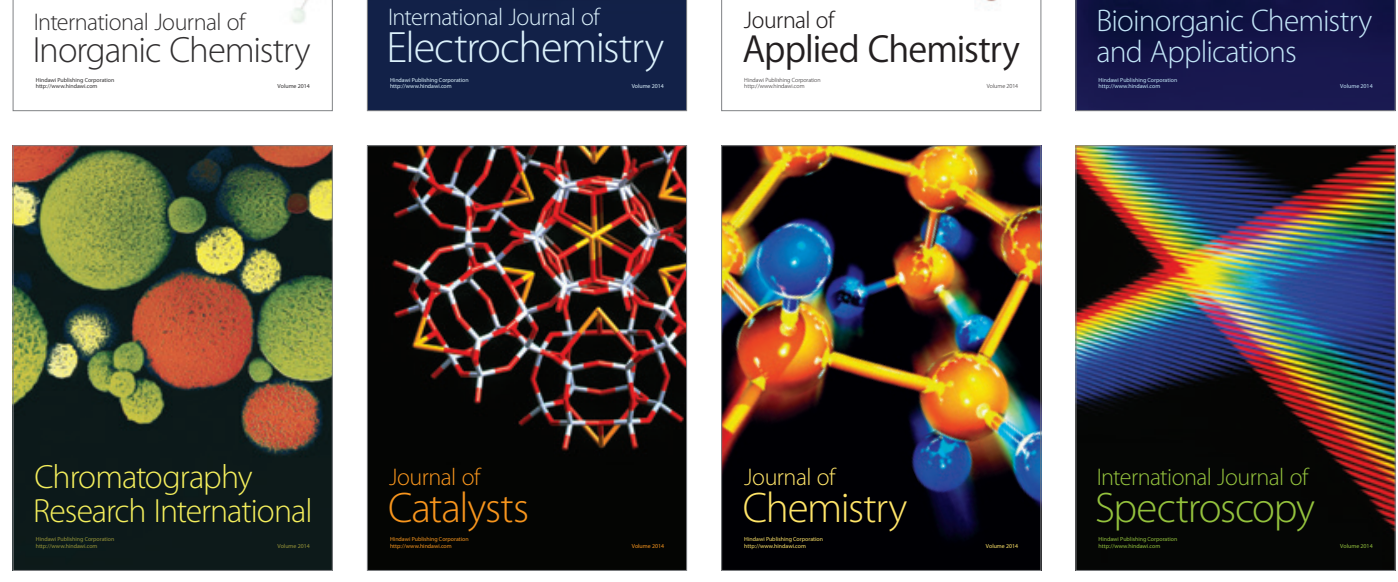